\title{
STIMULASI PENGEMBANGAN KECERDASAN VERBAL-LINGUISTIK ANAK USIA DINI MELALUI METODE PEMBELAJARAN PAUD
}

\author{
Dwi Haryanti \\ STAIN Syaikh Abdurrahman Siddik Bangka Belitung \\ Jl. Pahlawan 12 Petaling, Bangka 33173 Bangka Belitung \\ whiha90@gmail.com
}

\begin{abstract}
Everyone has their own intelligence on him. The scale of intelligence that has been used has many limitations so that it can not predict a successful performance in one's future. Intelligence possessed by a person needs to get attention in providing stimulation so as to develop optimally. Each individual has a different way of developing the various intelligences. That's why in the process of education and learning, especially every child must get different treatment according to the potential of intelligence that exist in each self. A person with high verbal linguistic intelligence can pay attention to a suitable language mastery. The storytelling method, the singing method, the role playing method, and the method of conversation are methods that can be done by the teacher in stimulating the verbal-linguistic intelligence of early childhood.

Keywords: Verbal Linguistic Intelligence, Early Childhood, Learning Methods.
\end{abstract}

\begin{abstract}
Abstrak
Setiap individu memiliki kecerdasan masing-masing pada dirinya. Skala kecerdasan yang selama ini digunakan ternyata memiliki banyak keterbatasan sehingga kurang dapat meramalkan kinerja yang sukses pada masa depan seseorang. Kecerdasan yang dimiliki oleh seseorang perlu mendapatkan perhatian dalam memberikan stimulasi sehingga mampu berkembang secara optimal. Setiap individu mempunyai cara yang berbeda-beda dalam mengembangkan berbagai kecerdasan tersebut. Untuk itulah dalam proses pendidikan dan pembelajaran khususnya setiap anak harus mendapat perlakuan yang berbeda-beda sesuai dengan potensi kecerdasan yang ada pada diri masing-masing.Seseorang dengan kecerdasan verbal linguistik yang tinggi dapat memperhatikan suatu penguasaan bahasa yang sesuai. Metode bercerita, metode bernyanyi, metode bermain peran, dan metode bercakapcakap adalah metode yang dapat dilakukan oleh pendidik dalam menstimulasi kecerdasan verbal-linguistik anak usia dini.

Kata kunci: Kecerdasan Verbal Linguistik, Anak Usia Dini, Metode Pembelajaran.
\end{abstract}

\section{Pendahuluan}

Inovasi-inovasi dalam dunia pendidikan kian terus terjadi, begitupun Pendidikan Anak Usia Dini. Perubahan- perubahan yang terjadi tersebut membawa tantangan dan peluang yang harus dihadapi. Kesadaran orangtua akan pentingnya memberikan stimulasi sejak usia dini 
semakin bertambah. Lebih dari $75 \%$ anak pada usia 4 tahun mengikuti jenis program prasekolah (play group) tertentu, dan sebanyak 1,3 juta lebih anak mengikuti pendidikan prasekolah yang merupakan dana dari pemerintah. ${ }^{1}$

Riset yang dilakukan oleh negara maju seperti Amerika mengafirmasi fakta bahwa pendidikan berkualitas tinggi sejak usia dini memiliki manfaat yang positif dan bertahan lama bagi anak di sepanjang hidup mereka. Pendidikan dini dan pengasuhan anak berkualitas memberikan manfaat jangka pendek dan jangka panjang khususnya bagi anak-anak yang berasal dari keluarga yang berpenghasilan rendah. ${ }^{2}$ Perbedaan signifikan pada cara pengasuhan anak di tahun-tahun pembentukan awal mereka terlihat pada cara mereka berkembang dan belajar. Ketika semuanya turut andil dalam mengasuh anak dan memberikan stimulus yang tepat bagi perkembangan mereka, maka seluruh masyarakat akan memetik buah yang baik. ${ }^{3}$

Pendidikan anak usia dini membutuhkan para professional yang terdidik dalam meng-update metodemetode mutakhir terbaru yang akan mendukung pelaksanaan pembelajaran

${ }^{1}$ George S. Morrison, Pendidikan Anak Usia Dini Saat Ini (Yogyakarta: Pustaka Pelajar, 2006), hlm. 4.

${ }^{2}$ Penelitian tersebut dilakukan oleh High Scope Perry Preschool Project serta Abecedarian Project dan Chicago Parent-Child Center (CPC).(Lihat lebih lengkap pada George S. Morrison).

${ }^{3}$ Pengasuhan yang baik tidak hanya didapatkan dari lingkungan keluarga saja, melainkan banyak hal yang mempengaruhi pertumbuhan dan perkembangan yang baik bagi anak, yakni lingkungan sekolah dan lingkungan masyarakat.
PAUD. Dukungan-dukungan tersebut merupakan salah satu yang dapat dilakukan dalam mengembangkan bakat dan potensi anak usia dini. Secara lahiriah, anak dilahirkan membawa bakat dalam dirinya.Bakat tersebut merupakan aset nasional sekaligus modal dasar pembangunan bangsa.

Pada masa keemasan anak, telah terjadi pembentukan sistem saraf secara mendasar.Pada masa ini, terjadi hubungan antara sel-sel saraf. Masa anak usia dini, perkembangan otak terjadi secara keseluruhan pada keempat bagian otak, termasuk pada masing-masing belahan otak. Belahan otak kanan dan kiri tersebut yang akan menyimpan kemampuan-kemampuan anak yang berbeda.

Berbagai penelitian pada otak manusia menyebutkan bahwa bayi yang baru dilahirkan memiliki lebih dari 100 miliar sel neuron yang siap dikembangkan.Pertumbuhan sel jaringan otak terjadi sangat pesat dan cepat pada tahun-tahun pertama kehidupan anak. Kurang lebih $80 \%$ jaringan otak pada anak telah tersusun pada saat anak mencapai usia 4 tahun. Jaringan otak tersebut akan terus berkembang dengan optimal apabila terdapat rangsangan-rangsangan (stimulant) dari luar. Rangsangan tersebut dapat berupa interaksi atau hal-hal yang dialami dan dipelajari oleh anak. Sebaliknya, jaringan sel otak tidak akan berfungsi dan bahkan akan mati (atrofi) jika otak tersebut tidak mendapatkan rangsangan-rangsangan yang tepat dari luar. ${ }^{4}$ Oleh sebab itulah, pendidikan yang diberikan kepada anak

${ }^{4}$ Arief Budiman, Mencerdaskan $I Q \& E Q$ Anak Anda Melalui Kinerja Otak (Bandung: Pustaka Setia, 2016), hlm. 21. 
sejak dini sangat penting. Hal ini dikarenakan pada masa tersebut (golden age), masa kritis anak lebih tinggi dibandingkan masa usia lainnya.

Hasil penelitian lain yang mendukung penelitian di atas dilakukan oleh Depdikbud dan menunjukkan hal yang sama dikemukakan oleh Munandar dalam Hamzah bahwa sepertiga peserta didik yang dapat digolongkan sebagai peserta didik berbakat mengalami gejala underachiever (prestasi kurang). ${ }^{5}$ Cukup banyak peserta didik berbakat yang prestasinya di sekolah tidak mencerminkan potensi intelektual mereka yang menonjol.Data yang diperoleh Balitbang Depdikbud menunjukkan bahwa hanya $2-5 \%$ dari seluruh peserta didik yang ada yang memiliki kemampuan dan kecerdasan luar biasa.Jumlah tersebut semakin meningkat pada jenjang pendidikan yang lebih tinggi, misalnya di tingkat SMA jumlah peserta didik berkemampuan dan berkecerdasan luar biasa mencapai $8 \%{ }^{6}$

Setiap individu memiliki keunggulan masing-masing pada dirinya. Tetapi, yang terjadi adalah banyak masyarakat awam yang beranggapan bahwa anak yang cerdas hanya diukur pada nilai matematika yang tinggi dan berprestasi pada bidang akademik saja.Inilah yang menjadi dasar seorang pakar kecerdasan, Howard Gardner melakukan penelitian kurang lebih selama 15 tahun untuk membuktikan tidak

${ }^{5}$ Hamzah B. Uno dan Masri Kuadrat, Mengelola Kecerdasan dalam Pembelajaran: Sebuah Konsep Pembelajaran Berbasis Kecerdasan (Jakarta: Bumi Aksara, 2010), hlm. 23.

${ }^{6}$ Ibid., hlm. 2-3. tepatnya hal tersebut. Gardner menegaskan bahwa skala kecerdasan yang selama ini digunakan ternyata memiliki banyak keterbatasan sehingga kurang dapat meramalkan kinerja yang sukses pada masa depan seseorang. Menurutnya, kecerdasan seseorang mencakup kecerdasan logismatematis, kecerdasan verbal-linguistik (bahasa), kecerdasan musikal, kecerdasan visual-spasial, kecerdasan kinestetik, kecerdasan interpersonal, kecerdasan intrapersonal, kecerdasan naturalis, dan kecerdasan spiritual-eksistensial.

Kecerdasan,sebagaimana yang dikemukakan oleh Gardner tersebut perlu mendapatkan perhatian dalam memberikan stimulasi sehingga mampu berkembang secara optimal. Setiap individu mempunyai cara yang berbeda-beda dalam mengembangkan berbagai kecerdasan tersebut. Untuk itulah dalam proses pendidikan dan pembelajaran khususnya setiap anak harus mendapat perlakuan yang berbeda-beda sesuai dengan potensi kecerdasan yang ada pada diri masingmasing. Seorang anak akan dapat belajar bidang pengembangan apapun apabila dia diberi kesempatan untuk mempelajarinya sesuai dengan kecerdasan yang dimiliki.7Sangat mungkin terjadi seorang anak belajar matematika melalui kecerdasan linguistik pada diri anak.

\section{Pembahasan}

"Setiap anak adalah bintang dan cahayanya berpendar indah manakala diamati dengan teropong bintang MIR yang

${ }^{7}$ Istilah tersebut dikenal sebagai "the right man on the right competence". Selengkapnya lihat Yuliani Nurani Sujiono dan Bambang Sujiono, Bermain Kreatif Berbasis Kecerdasan Jamak, hlm. 52. 
memetakan berbagai sisi kecerdasan majemuk sang bintang".(Lyra Puspa dalam Munif Chatib) ${ }^{8}$. Kalimat inspirasi di atas merupakan salah satu gambaran bahwa seorang anak tidak akan pernah bercahaya jika tidak dibarengi oleh situasi dan kondisi yang mendukung tumbuhkembangnya. Mirisnya, banyak kejadian yang kita dengar, bahkan sangat dekat dengan kehidupan kita, seorang Ibu menganggap anaknya bodoh, bahkan dicap sebagai anak bodoh hanya dikarenakan nilai pada hasil belajar (raport) tidak sesuai dengan harapan sang Ibu. Seperti halnya Thomas Alva Edison dan Albert Einstein yang dianggap bodoh oleh gurunya.Thomas Alva Edison dikeluarkan dari sekolah formal karena dianggap bodoh dan sering merepotkan gurunya dengan pertanyaan-pertanyaan nyeleneh bagi seorang anak seusinya.Namun pada akhirnya, Edison adalah ilmuwan paling bersinar karena penemuannya. Begitupun Albert Einstein, yang dianggap bodoh karena pertanyaanpertanyaan dan perilakunya dianggap aneh. Einstein kecil pernah berperilaku seperti ayam dengan cara "mengerami" telur ayam untuk mengetahui "bagaimana proses ayam sampai menetaskan telurnya." Namun tak disangka, Albert Einstein kemudian menjadi ilmuwan hebat yang masih dikenal sampai saat ini. ${ }^{9}$

${ }^{8}$ Lyra Puspa adalah Presiden Vanaya Coaching Institute dan Ketua Umum Asosiasi Sinergi Terapan Neourosains Indonesia. Lihat Munif Chatib, Semua Anak Bintang: Menggali Kecerdasan dan Bakat Terpendam dengan Multiple Intelligence Research (MIR), (Bandung: Kaifa, 2017), hlm. VII

${ }^{9}$ Alamsyah Said dan Andi Budimanjaya, 95 Strategi Mengajar Multiple Intelligence (Jakarta: Kencana, 2015), hlm. 6.
Setiap kecerdasan yang ada dalam diri seseorang mempunyai riwayat perkembangan.Kecerdasan bukanlah merupakan ciri mutlak yang sudah ditetapkan sejak anak terlahir ke dunia.Kecerdasan bukan pula hal permanent yang tidak bisa diubah sepanjang hidup seseorang.Menurut teori MI (Multiple Intelligence), setiap kecerdasan muncul pada titik tertentu di masa kanak-kanak, mempunyai periode yang berpotensi untuk berkembang selama rentang kehidupan yang dialami.

\section{Pengertian Kecerdasan}

Kecerdasan merupakan sebuah istilah yang sulit jika harus didefinisikan karena menimbulkan pemahaman yang berbeda-beda di kalangan para ilmuwan.Menurut Howard Gardner dalam Munif, kecerdasan seseorang tidak dapat diwakili dengan angka-angka atau sekedar hasil tes IQ semata. ${ }^{11}$ Kecerdasan berasal dari habit (kebiasaan) seseorang. Maksudnya bahwa kebiasaan tersebut cenderung dilakukan secara berulang-ulang.

Pengertian kecerdasan menurut Bainbridge dalam Yaumi mengutarakan bahwa kecerdasan merupakan kemampuan mental umum untuk belajar dan menerapkan pengetahuan dalam memanipulasi lingkungan, serta kemampuan berpikir abstrak. Sementara Fritz (dalam Yaumi) juga berpendapat bahwa kecerdasan mencakup kemampuan beradaptasi dengan lingkungan baru atau

${ }^{10}$ Thomas Amstrong, Kinds of Smart: Menemukan dan Meningkatkan Kecerdasan Anda Berdasarkan Teori Multiple Intelligence (Jakarta: Gramedia Pustaka Utama, 2005), hlm. 7.

${ }^{11}$ Munif Chatib, Semua Anak Bintang..., hlm. 
perubahan lingkungan saat ini, kemampuan untuk mengevaluasi dan menilai, kemampuan untuk memahami ide-ide yang kompleks, kemampuan untuk berpikir produktif, kemampuan untuk belajar dengan cepat dan belajar dari pengalaman dan bahkan kemampuan untuk memahami hubungan. ${ }^{2}$ Munif Chatib dalam bukunya juga memberikan pandangan bahwa kecerdasan adalah kemampuan seseorang yang disebut kecerdasan yakni yang mampu membawa manfaat atau benefit positif bagi dirinya dan orang lain. ${ }^{13}$

Sehingga dari beberapa pendapat di atas, dapat dikemukakan bahwa kecerdasan merupakan kemampuan seseorang dalam menyelesaikan masalah sendiri, kemampuan seseorang dalam menciptakan sesuatu yang baru (baik berupa ide maupun produk), kemampuan seseorang dalam beradaptasi terhadap lingkungan yang dialami, serta kemampuan seseorang dâlam memberikan manfaat kepada orang lain.

\section{Kecerdasan Verbal-Linguistik (Cerdas Berbahasa)}

Kecerdasan Verbal-Linguistik merupakan salah satu dari Multiple Intelligence yang diungkapkan oleh Howar Gardner.Kecerdasan Verbal-Linguistik atau biasa disebut dengan cerdas berbahasa merupakan salah satu unsur dari kecerdasan majemuk. Dalam kegiatan

${ }^{12}$ Muhammad Yaumi dan Nurdin Ibrahim, Pembelajaran Berbasis Kecerdasan Jamak (Multiple Intelligences): Mengidentifikasi dan Mengembangkan Multitalenta Anak (Jakarta: Kencana, 2013), hlm. 9. hlm. 8 . sehari-hari kecerdasan bahasa merupakan salah satu kecerdasan yang penting, karena kecerdasan linguistik berkaitan dengan kemampuan berbicara.

Pengembangan kecerdasan verballinguistik anak usia dini melalui berbagai strategi dan aktivitas mendidik yang dapat membantu mengoptimalkan kemampuan bahasa anak usia dini. Kemampuan berbahasa yang dimaksudmencakup kemampuan berbicara, membaca, menyimak atau mendengarkan dan menulis.

Seseorang dengan kecerdasan verbal linguistik yang tinggi dapat memperhatikan suatu penguasaan bahasa yang sesuai. Orang-orang tersebut dapat memceritakan kisah, berdebat, berdiskusi, menafsirkan, menyampaikan laporan, dan melaksanakan berbagai tugas lain yang berkaitan dengan berbicara dan menulis serta dapat dengan mudah mempengaruhi orang lain melalui kata-katanya.

Kecerdasan linguistik-verbal atau dikenal dengan istilah pintar kata adalah kemampuan untuk menggunakan bahasa baik lisan maupun tulisan secara tepat dan akurat. Menggunakan kata merupakan cara utama untuk berpikir dan menyelesaikan masalah bagi orang yang memiliki kecerdasan ini. Mereka cenderung mempunyai keterampilan reseptif (input) auditori dan produktif(output) verbal yang sangat baik. Mereka menggunakan kata untuk membujuk, mengajak, membantah, menghibur, atau membelajarkan orang lain. ${ }^{14}$

Menurut Amstrong dalam Sujiono mengemukakan bahwa kecerdasan linguistik adalah kecerdasan dalam 
mengolah kata atau kemampuan menggunakan kata secara efektif baik secara lisan maupun secara tertulis.Seseorang dikatakan cerdas bahasa apabila dia dapat berargumentasi, menyakinkan orang lain, menghibur atau mengajar dengan efektif lewat kata-kata yang diutarakannya. ${ }^{15}$

Dalam kegiatan sehari-hari kecerdasan linguistik merupakan salah satu kecerdasan yang penting, karena kecerdasan linguistik berkaitan dengan kemampuan berbicara. Sulit dipahami jika kita sampai tidak mengenal individu dengan kecerdasan bahasa yang dimiliki.Karena jelas terlihat bahwa individu yang mempunyai kemampuan berbicara maupun menulis, sangat menonjol pada bidang ini.Mereka membawakan dirinya dengan baik seçara verbal dan kelihatannya selalu mengetahui hal yang tepat untuk dikatakan.

Kecerdasan linguistik adalah kecerdasan dalam mengelola kata, atau kemampuan menggunakan kata secara efektif baik secara lisan maupun tertulis.Kecerdasan linguistik meliputi kepekaan terhadap arti kata, urutan kata, suara, ritme, dan intonasi dari kata diucapkan. Termasuk kemampuan untuk mengerti kekuatan kata dalam mengubah kondisi pikiran dan penyampaian informasi. ${ }^{16}$

Berdasarkan pendapat para ahli mengenai pengertian kecerdasan

${ }^{15}$ Yuliani Nurani Sujiono dan Bambang Sujiono, Bermain Kreatif Berbasis Kecerdasan Jamak (Jakarta: Indeks, 2010), hlm. 55-57.

${ }^{16} \mathrm{~A}$. Indragiri, KECERDASAN OPTIMAL Cara Ampuh Memaksimalkan Kecerdasan Anak, (Jogjakarta: STARBOOKS, 2010), hlm. 15. linguistik dapat disimpulkan bahwa kecerdasan linguistik adalah kemampuan seseorang dalam menggunakan atau mengolah gagasan yang akan disampaikan kepada orang lain melalui kata-kata atau bahasa. Jadi kecerdasan linguistik mempengaruhi kemampuan seseorang dalam mengkomunikasikan gagasannya.

Kecerdasan ini mencakup kepekaan terhadap arti kata, urutan kata, suara, ritme, dan intonasi dari kata yang diucapkan. Termasuk kemampuan untuk mengerti kekuatan kata dalam mengubah kondisi pikiran dan menyampaikan informasi. Kecerdasan ini biasanya dikaitkan langsung dengan anak yang cerdas di sekolah. Meskipun demikian, anak yang tidak sekolah bukan berati tidak mempunyai kecerdasan linguistik. ${ }^{17}$

Kecerdasan berbahasa sangat dihargai dalam era modern yang sekarang sedang kita alami. Hal ini dikarenakan orang cenderung menilai orang lain dari cara mereka berbicara dan menulis. Kemampuan berbicara seseorang merupakan salah satu aspek yang paling penting digunakan oleh seseorang dalam membentuk kesan pertama. Seseorang yang mempunyai kecerdasan berbahasa yang tinggi tidak hanya akan memperlihatkan suatu penguasaan bahasa yang sesuai, tetapi juga menceritakan kisah, berdebat, berdiskusi, menafsirkan, menyampaikan laporan, dan melaksanakan berbagai tugas lain yang berkaitan dengan bicara dan menulis. Kecerdasan linguistic sejatinya terdiri dari penguasaan berbagai komponen bahasa seperti fonetik, sintaksis, semantik,

\footnotetext{
${ }^{17}$ Susanti, Werdiningsih Febriana dan Sujiyanti, Mencetak Anak Juara, (Jogjakarta:KATAHATI, 2009), hlm. 15-16.
} 
morfenik, dan pragmatik ${ }^{18}$.Pekerjaan yang mengandalkan kehebatan seseorang dalam bermain kata-kata cukup banyak ditemui dan mempunyai jumlah yang cukup besar, termasuk profesi sebagai pengacara (ranah hukum), reporter dan wartawan (ranah penulisan), guru, pendongeng, penulis, kepala sekolah, pelawak, pembaca berita di radio atau telivisi, editor suara kabar, penyair, serta banyak lagi profesi lain yang berhubungan dengan kecerdasan verballinguistik. ${ }^{19}$

Seorang individu yang
mempunyai kecerdasan verbal-linguistik cukup baik memiliki kemampuan untuk menghargai kata-kata dan makna dari kata-kata tersebut.Mereka mengembangkan kepekaan bahasa yang tajam dan dengan mudah dapat memanipulasi struktur dan sintaksisnya untuk menyesuaikan dengan setiap

${ }^{18}$ Pengetahuan fonetik merujuk kepada pengetahuan mengenai hubungan bahasa-simbol dalam bahasa. Fonem merupakan unit linguistic terkecil berbentuk bunyi, yang membentuk kata jika bergabung dengan fonem yang lain. Fonem terdiri dari bunyi-bunyi yang dianggap sebagai satu unit yang dimengerti oleh pendengar, seperti bunyi /m/ pada kata mama (hlm.5).Pengetahuan semantik merujuk kepada penamaan kata yang memerincikan suatu konsep dan juga jaringan semantik atau skemata, yang menunjukkan hubungan timbal balik antarkonsep.(hlm.8). istilah sintaksis yakni menggabungkan kata-kata untuk membentuk ekspresi yang bermakna.Setiap system bahasa memiliki aturan atau tata bahasa yang menentukan bagaimana kata-kata digabungkan untuk membentuk kalimat atau frasa atau ujaran yang bermakna.(hlm. 10).Sedangkan morfemik merujuk kepada pengetahuan struktur kata, dan pragmatik meliputi pengetahuan atau kesadaran terhadao keseluruhan maksud komunikasi dan bagaimana bahasa digunakan untuk memperoleh maksud tersebut. Lihat Beverly Otto, Perkembangan Bahasa Pada Anak Usia Dini (Jakarta: Kencana, 2015). hlm. 45 . kebutuhan.

Pemikiran berciri linguistik biasanya mahir pula memanipulasi struktur atau susunan kalimat bahasa. Misalnya Marcel Proust, ia mampu merangkai anak kalimat menjadi kalimat satu paragraf untuk menciptakan dampak yan menakjubkan. ${ }^{20}$ Adapun ciri-ciri anak yang mempunyai kecerdasan linguistik, yakni: (1) biasanya mempunyai keterampilan pendengaran yang sangat berkembang dan menikmati bermain-main dengan bunyi bahasa, (2) suka membaca dan menulis cerita atau puisi, (3) sangat hafal nama, tempat, tanggal, atau halhal kecil, (4) mengeja kata dengan tepat dan mudah, (5) suka mengisi teka-teki silang, (6) menikmati dengan cara mendengarkan, serta (7) unggul dalam mata pelajaran bahasa (membaca, menulis, dan berkomunikasi). ${ }^{21}$

\section{Metode Pembelajaran untuk Pengembangan Kecerdasan Verbal- Linguistik}

Secara umum, cara yang dapat digunakan dalam mengembangkan kecerdasan verbal-linguistik sebagaimana yang dikemukakan oleh Gunawan sebagai berikut:

(a) Menjadi pendengar yang efektif

Untuk bisa menjadi pendengar yang efektif, pertama-tama yang dapat dilakukan adalah harus bisa mencari atau menemukan hal yang menarik dari apa yang sedang dibicarakan oleh orang lain. Sebagaimana metode ceramah yang dilakukan, maka seorang akan lebih mendengarkan perkataan orang lain, walaupun kadang-kadang

${ }^{20}$ Thomas Amstrong, Seven Kinds of Smart, (Jakarta: PT Gramedia Pustaka Utama, 2002), hlm.21.

${ }^{21}$ Susanti, Mencetak Anak..., hlm. 16 
muncul rasa bosan. Kedua, jangan terlalu terpengaruh dengan cara penyampaian informasi atau suatu ide. Yang perlu diperhatikan bukanlah caranya, tetapi isi atau informasi yang disampaikan. Selain itu, untuk menjadi pendengar yang efektif, seseorang harus bisa menahan diri untuk tidak langsung memotong pembicaraan. Kebanyakan orang hanya akan berdiam diri sebentar sambil menunggu kesempatan untuk memotong pembicaraan dan memanfaatkan kesempatan itu untuk mulai berbicara.Selama mendengarkan lawan berbicara, berusahalah untuk fokus memperhatikan. Jangan mudah terpengaruh dengan sesuatu yang tidak penting seperti suara telepon atau hal lain. Selama kita fokus mendengarkan, kita harus memberikan kesan bahwa lawan bicara kita adalah orang penting. ${ }^{22}$

(b) Melatih keahlian berbicara

Ada beberapa hal yang dapat dilakukan untuk melatih keahlian dalam berbicara.Misalnya bergabung dengan suatu organisasi.Untuk melatih kemampuan bicara, seseorang dapat bergabung dengan organisasi-organisasi dengan begitu rasa percaya diri yang dibangun melalui organisasi akan sangat berguna untuk meningkatkan kemampuan-kemampuan yang lain. Selain bergabung dalam organisasi, mengarang cerita dengan memilih kata secara acak juga bisa digunakan dalam melatih kemampuan berbicara.Caranya sangat mudah, ambilah sebuah kamus. Lalu buka kamus itu secara acak dan

${ }^{22}$ Adi W Gunawan., Born to Be a Genius, (Jakarta: PT Gramedia Pustaka Utama, 2011), hlm. 108-109 gunakan untuk menunjuk pada suatu kata. Kemudian buatlah suatu cerita dengan menggunakan kata yang telah dipilih secara acak sebagai topik pembicaraan.

Selanjutnya, Maimunah Hasan menyebutkan beberapa cara yang dapat digunakan dalam merangsang kecerdasan verbal linguistik anak usia dini, yakni: metode bercakap-cakap, metode bercerita dan metode bernyanyi. ${ }^{2}$

a. Metode bercakap-cakap

Bercakap-cakap berkembang menjadi suatu dialog dikarenakan melibatkan dua orang atau lebih. Manfaat yang diperoleh dari bercakap-cakap sebagai berikut: (1) meningkatkan keberanian anak untuk berbicara, (2) melatih kemampuan anak untuk mendengarkan pembicaraan dan menangkap pesan dari orang lain, (3) membangun konsep diri yang positif, (4) memperluas pengetahuan dan meningkatkan perbendaharaan kosakata yang dimiliki oleh anak, serta (5) meningkatkan keberanian anak untuk mengadakan hubungan dengan orang lain, yakni guru dan teman sebaya. ${ }^{24}$

\section{b. Metode bercerita}

Bercerita merupakan cara bertutur dan menyampaikan cerita atau memberikan penjelasan secara lisan. Bercerita juga merupakan bentuk untuk menyampaikan nilai-nilai yang berlaku di masyarakat.Isi cerita yang disampaikan diusahakan berhubungan dengan dunia kehidupan anak yang penuh kegembiraan, yang menuntut isi cerita memiliki unsur yang

${ }^{23}$ Maimunah Hasan, PAUD (Pendidikan Anak Usia Dini), (Yogyakarta: Diva Press, 2009), hlm. 119.

${ }^{24}$ Mukhtar Latif, dkk, Orientasi Baru Pendidikan Anak Usia Dini: Teori dan Aplikasi (Jakarta: Kencana, 2013), hlm. 115. 
dapat memberikan perasaan gembira, lucu, menarik dan mengasyikkan bagi anak.Isi cerita pun harus disesuaikan dengan minat anak yang biasanya berkenaan dengan tema-tema yang ada dalam pembelajaran PAUD, misalnya berhubungan dengan binatang, tanaman, kendaraan, planet, lingkungan, diri sendiri, dan lain sebagainya.Isi cerita juga harus sesuai dengan tingkat usia, kebutuhan, dan kemampuan anak mengangkap usu cerita yang berbeda-beda, sehingga cerita diharapkan harus bersifat ringkas atau pendek dalam rentang perhatian anak. Sebagai seorang pendidik, ada beberapa cara yang dapat dilakukan oleh guru:

(1) Membaca langsung dari buku cerita;

(2) Menceritakan dongeng;

(3) Bercerita dengan menggunakan ilustrasi gambar dari buku;

(4) Bercerita menggunakan pàpan flannel;

(5) Bercerita dengan menggunakan media boneka; serta

(6) Bercerita dengan menggunakan atau memainkan jari-jari tangan. ${ }^{25}$

c. Metode bernyanyi

Bernyanyi memiliki banyak manfaat untuk pembelajaran anak usia dini, yakni: (1) bernyanyi dapat menyenangkan anak; (2) bernyanyi dapat dipakai untuk mengatasi kecemasan; (3) bernyanyi merupakan media untuk mengekspresikan perasaan; (4) bernyanyi dapat

${ }^{25}$ Ibid., hlm. 112. membantu menumbuhkan rasa percaya diri anak; (5) bernyanyi dapat meningkatkan daya ingat anak; (6) bernyanyi dapat mengembangkan keterampilan berpikir dan kemampuan motorik anak. ${ }^{26}$ Melalui metode bernyanyi, kosa kata anak akan bertambah. Sehingga salah satu metode yang efektif dalam mengembangkan kecerdasan anak usia dini adalah dengan metode bernyanyi.

Sementara itu, Arief Budiman mengemukakan bahwa kecerdasan bahasa dapat dioptimalkan dengan berbagai cara, antara lain: 27

a. Anak diarahkan untuk belajar berbicara di depan orangtua atau orang lain;

b. Anak yang cenderung pendiam dapat dioptimalkan kecerdasan bahasanya dengan cara diarahkan untuk mengarang atau membuat tulisan mengenai hal-hal yang disukai anak;

c. Anak diarahkan untuk banyak membaca buku-buku yang disukainya, sehingga otak anak akan banyak merekan dan mengingat kata-kata. Selain itu, membaca dapat menambah wawasan serta memperbanyak perbendaharaan anak.

Menurut Yuliani Nurani Sujiono, tujuan dalam mengembangkan kecerdasan linguistik antara lain: (1) agar anak mempunyai kemampuan untuk berkomunikasi dengan baik dan efektif, (2) memiliki kemampuan bahasa untuk menyakinkan orang lain, (3) mempunyai kemampuan untuk mengingat dan menghafal informasi, (4) memiliki kemampuan untuk memberikan

${ }^{26}$ Ibid., hlm. 113

${ }^{27}$ Arief Budiman, Mencerdaskan ..., hlm.

135. 
penjelasan dan, (5) mampu untuk membahas bahasa itu sendiri. ${ }^{28}$

Materi program kurikulum pada pembelajaran anak usia dini yang dapat mengembangkan kecerdasan linguistik sebagai berikut: abjad, bunyi, ejaan, membaca, menulis, menyimak, berbicara atau berdiskusi dan menyampaikan laporan secara lisan, bermain games atau mengisi teka-teki silang. Stimulus yang tepat dalam mengembangkan kecerdasan verbal-linguistik berdampak pada anak ketika memasuki jenjang kehidupan selanjutnya. Yuliani menambahkan bahwa cara yang bisa dilakukan untuk mengembangkan kecerdasan linguistik pada anak sejak usia dini, antara lain dapat dilakukan dengan cara-cara berikut ini:

a.) Mengajak anak berbicara

b.) Membaca cerita

c.) Bermain huruf

d.) Merangkai cerita

e.) Berdiskusi atau bercakap-cakap

f.) Bermain peran

g.) Memperdengarkan lagu anak-anak. ${ }^{29}$

Pada dasarnya, banyak metode yang dapat digunakan seorang pendidik dalam menstimulasi kecerdasan verballinguistik untuk anak usia dini. Sebagaimana yang telah dikemukakan beberapa tokoh tentang cara mengembangkan kecerdasan verballinguistik anak usia dini, beberapa persamaan yang dapat diaplikasikan oleh pendidik yakni menggunakan metode bercerita. Metode bercerita merupakan

${ }^{28}$ Yuliani Nurani Sujiono, Konsep Dasar Pendidikan Anak Usia Dini( Jakarta: Indeks, 2013), hlm. 185.

${ }^{29}$ Ibid., hlm.186-187 metode yang paling sering digunakan oleh pendidik dalam menyampaikan materi yang tercantum pada tema pembelajaran. Metode ini akan lebih menyenangkan dan menarik perhatian anak apabila dilakukan dengan menggunakan media (misalnya media boneka tangan, panggung boneka, dan media gambar) serta dalam pengucapannya, menggunakan intonasi tinggi rendah (menirukan suara-suara binatang atau suara lainnya akan membuat anak fokus dalam mendengarkan cerita.

Kedua, metode bernyanyi. Metode ini hampir diterapkan oleh pendidik setiap harinya dalam proses pembelajaran. Biasanya metode bernyanyi dilakukan pada setiap kegiatan, baik pada kegiatan pembuka, kegiatan inti, maupun kegiatan penutup.Ketiga, metode bermain peran.Bermain peran atau biasa disebut dengan main pura-pura, main drama, merupakan metode yang langsung melibatkan anak berperan sesungguhnya dan menjadi seseorang atau sesuatu. Dengan bermain peran, anak belajar banyak keterampilan, misalnya mendengarkan, tetap dalam tugas, menyelesaikan masalah dan bermain kerja sama dengan orang lain. Bermain peran dapat memberikan pengalaman kepada anak bagaimana anak tersebut menghadapi serangan dari luar terhadap egonya.

\section{Kesimpulan}

Setiap individu mempunyai cara yang berbeda-beda dalam mengembangkan berbagai kecerdasan yang dimiliki. Untuk itulah dalam proses pendidikan dan pembelajaran khususnya setiap anak harus mendapat perlakuan yang berbeda-beda sesuai dengan potensi kecerdasan yang ada 
pada diri masing-masing. Seorang anak akan dapat belajar bidang pengembangan apapun apabila dia diberi kesempatan untuk mempelajarinya sesuai dengan kecerdasan yang dimiliki.

Kecerdasan secara umum merupakan kemampuan seseorang dalam menyelesaikan masalah yang dihadapi, kemampuan seseorang dalam memberikan kontribusi baik secara materiil maupun moril pada lingkungan sekitar.Beberapa kecerdasan yang dikemukakan oleh Howard Gardner, salah satunya adalah kecerdasan verballinguistik.Kecerdasan verbal-linguistik merupakan kemampuan untuk menggunakan kata-kata secara efektif, baik secara lisan maupun tulisan. Kecerdasan ini mencakup kepekaan terhadap arti kata, urutan kata, suara, ritme dan intonasi dari kata yang di ucapkan. Termasuk kemampuan untuk mengerti kekuatan kata dalam mengubah kondisi pikiran dan menyampaikan informasi.Anak yang cerdas dalam berbahasa, cenderung memiliki daya ingat yang kuat dan hal-hal yang sifatnya detail. Dalam menguasai bahasa baru, anak-anak yang mempunyai kecerdasan bahasa pada umumnya memiliki kemampuan yang lebih tinggi dibandingkan anak-anak lain.

Metode pembelajaran yang dapat diterapkan oleh pendidik dalam memberikan stimulus pengembangan kecerdasan verbal-linguistik antara lain dengan menggunakan metode bercerita, metode bernyanyi, metode bermain peran, dan metode bercakap-cakap. Sementara itu, anak-anak juga perlu dilatih dalam mengembangkan kecerdasan verballinguistik dengan senantiasa mengarahkan anak menceritakan apa yang dialaminya. Siapkan buku-buku menarik dan menyenangkan bagi anak sehingga dengan banyak membaca, perbendaharaan kata pada anak dapat terus bertambah.

\section{Daftar Pustaka}

Amstrong, Thomas. Kinds of Smart:Menemukan dan Meningkatkan Kecerdasan Anda Berdasarkan Teori Multiple Intelligence. (Jakarta: Gramedia Pustaka Utama, 2005).

Budiman, Arief. Mencerdaskan IQ \& EQ Anak Anda Melalui Kinerja Otak. (Bandung: Pustaka Setia, 2016).

B. Uno, Hamzah dan Masri Kuadrat. Mengelola Kecerdasan dalam Pembelajaran: Sebuah Konsep Pembelajaran Berbasis Kecerdasan. (Jakarta: Bumi Aksara, 2010).

Chatib, Munif. Semua Anak Bintang: Menggali Kecerdasan dan Bakat Terpendam dengan Multiple Intelligence Research (MIR). (Bandung: Kaifa, 2017).

Gunawan, Adi W. Born to Be a Genius. (Jakarta: PT Gramedia Pustaka Utama, 2011).

Hasan, Maimunah. PAUD (Pendidikan Anak Usia Dini). (Yogyakarta: Diva Press, 2009).

Indragiri A. KECERDASAN OPTIMAL Cara Ampuh Memaksimalkan Kecerdasan Anak. (Jogjakarta: STARBOOKS, 2010).

Latif, Mukhtar, dkk,. Orientasi Baru Pendidikan Anak Usia Dini: Teori dan Aplikasi. (Jakarta: Kencana, 2013).

Nurani Sujiono, Yuliani. Konsep Dasar 
Pendidikan Anak Usia Dini. (Jakarta: PT Indeks, 2013)

Nurani Sujiono, Yuliani dan Bambang Sujiono. Bermain Kreatif Berbasis Kecerdasan Jamak. (Jakarta: Indeks, 2010).

Otto, Beverly. Perkembangan Bahasa Pada Anak Usia Dini. (Jakarta: Kencana, 2015).

S. Morrison, George. Pendidikan Anak Usia Dini Saat Ini. (Yogyakarta: Pustaka Pelajar, 2006).
Said, Alamsyah dan Andi Budimanjaya. 95 Strategi Mengajar Multiple Intelligence. (Jakarta: Kencana, 2015).

Susanti, Febriana Werdiningsih, Sujiyanti. Mencetak Anak Juara. (Jogjakarta: KATAHATI, 2009).

Yaumi, Muhammad dan Nurdin Ibrahim. Pembelajaran Berbasis Kecerdasan Jamak (Multiple Intelligences): Mengidentifikasi dan Mengembangkan Multitalenta Anak. (Jakarta: KENCANA, 2013). 